\title{
WALTER SCOTT AND THE GREENING OF SCOTLAND
}

The work of Walter Scott, one of the most globally influential authors of the nineteenth century, provides us with a unique narrative of the changing ecologies of Scotland over several centuries, inscribing that narrative into the history of environmental literature. Farmland, mountains, moors and forests, along with rivers, shorelines, islands and oceans, are systematically explored, situating Scott's writing about shared human and nonhuman environments in the context of the emerging Anthropocene. Susan Oliver attends to changes and losses acting in counterpoint to the narratives of 'improvement' that underpin modernization in land management. She investigates the imaginative ecologies of folklore and local culture. Each chapter establishes a dialogue between ecocritical theory and Scott as storyteller of social history. This a book that shows how Scott challenged conventional assumptions about the permanency of stone and the evanescence of air; it begins with the land and ends by looking at the stars.

susan oliver is Professor of Literature and Dean of Research in the Faculty of Arts and Humanities, University of Essex. She is the winner of the British Academy's Rose Mary Crawshay Prize for Scott, Byron and the Poetics of Cultural Encounter (2006) and is also the editor of The Yearbook of English Studies: New Approaches to Walter Scott (2017). 


\author{
Founding Editor \\ Marilyn Butler, University of Oxford \\ General Editor \\ James Chandler, University of Chicago \\ Editorial Board \\ John Barrell, University of York \\ Paul Hamilton, University of London \\ Mary Jacobus, University of Cambridge \\ Claudia Johnson, Princeton University \\ Alan Liu, University of California, Santa Barbara \\ Deidre Lynch, Harvard University \\ Jerome McGann, University of Virginia \\ David Simpson, University of California, Davis
}

This series aims to foster the best new work in one of the most challenging fields within English literary studies. From the early I780s to the early I 830 , a formidable array of talented men and women took to literary composition, not just in poetry, which some of them famously transformed, but in many modes of writing. The expansion of publishing created new opportunities for writers, and the political stakes of what they wrote were raised again by what Wordsworth called those 'great national events' that were 'almost daily taking place': the French Revolution, the Napoleonic and American wars, urbanization, industrialization, religious revival, an expanded empire abroad, and the reform movement at home. This was an enormous ambition, even when it pretended otherwise. The relations between science, philosophy, religion, and literature were reworked in texts such as Frankenstein and Biographia Literaria; gender relations in $A$ Vindication of the Rights of Woman and Don Juan; journalism by Cobbett and Hazlitt; and poetic form, content, and style by the Lake School and the Cockney School. Outside Shakespeare studies, probably no body of writing has produced such a wealth of commentary or done so much to shape the responses of modern criticism. This indeed is the period that saw the emergence of those notions of literature and of literary history, especially national literary history, on which modern scholarship in English has been founded.

The categories produced by Romanticism have also been challenged by recent historicist arguments. The task of the series is to engage both with a challenging corpus of Romantic writings and with the changing field of criticism they have helped to shape. As with other literary series published by Cambridge University Press, this one will represent the work of both younger and more established scholars on either side of the Atlantic and elsewhere.

See the end of the book for a complete list of published titles. 


\title{
WALTER SCOTT AND THE \\ GREENING OF SCOTLAND
}

Emergent Ecologies of a Nation

\author{
SUSAN OLIVER \\ University of Essex
}




\section{CAMBRIDGE \\ UNIVERSITY PRESS}

University Printing House, Cambridge св 2 8вs, United Kingdom

One Liberty Plaza, 2oth Floor, New York, NY I0oo6, USA

477 Williamstown Road, Port Melbourne, vic 3207, Australia

3 I 4-32 I, 3rd Floor, Plot 3, Splendor Forum, Jasola District Centre,

New Delhi - I 10025 , India

I03 Penang Road, \#05-06/07, Visioncrest Commercial, Singapore 238467

Cambridge University Press is part of the University of Cambridge.

It furthers the University's mission by disseminating knowledge in the pursuit of education, learning, and research at the highest international levels of excellence.

www.cambridge.org

Information on this title: www.cambridge.org/978 I I08831574

DOI: IO.IOI7/978 I I089I7674

(C) Susan Oliver 202I

This publication is in copyright. Subject to statutory exception and to the provisions of relevant collective licensing agreements, no reproduction of any part may take place without the written permission of Cambridge University Press.

First published 202I

A catalogue record for this publication is available from the British Library.

ISBN 978-I-I O8-83 I 57-4 Hardback

Cambridge University Press has no responsibility for the persistence or accuracy of URLs for external or third-party internet websites referred to in this publication and does not guarantee that any content on such websites is, or will remain, accurate or appropriate. 
For Jonathan 


\section{Contents}

List of Illustrations

page viii

Acknowledgements

ix

Chronology of Works Referenced xii

I Introduction: Walter Scott and the Environment I

2 Shifting Ecologies: Grasslands, Rivers and Shorelines 28

3 Toxic Ecologies, Ecogothic and Violence against the Land 64

4 Wild Places, Rarity and Extinction 88

5 Trees 1 I 3

6 Stone, Water, Air 140

Notes $\quad$ I 8 I

Bibliography $\quad 207$

Index 222 


\title{
C HAPTER I \\ Introduction \\ Walter Scott and the Environment
}

\begin{abstract}
Breathes there the man, with soul so dead, Who never to himself hath said,

This is my own, my native land!
\end{abstract}

Walter Scott, The Lay of the Last Minstrel ${ }^{\mathrm{I}}$

Ettrick Forest boasts finely shaped hills and clear romantic streams; but, alas! they are bare, to wildness, and denuded of the beautiful natural wood with which they were formerly shaded.

Walter Scott to George Ellis, 19 May I $804^{2}$

Not so much of all literature survives

As any wisp of scriota that thrives

On a rock...

These bare stones bring me straight back to reality.

Hugh MacDiarmid, from On a Raised Beach: a Poem ${ }^{3}$

This book's central argument is that Walter Scott, one of the most globally influential and popular writers of the nineteenth century, needs to be reread so that the full extent of his contribution to environmental literature and ecological historiography can be understood. That contribution is as remarkable as it is neglected. Scott has been studied almost entirely for the ways in which he explored the relationships between human communities and their socio-political development. Since he was educated in the Edinburgh of the Scottish Enlightenment, that approach might be expected. Yet natural science was also a key area of Scottish Enlightenment enquiry, and one of its more important intellectual and literary exports.

The move from Enlightenment science to Romantic nature writing, with its emphasis on feeling as a means to knowledge, sharpens the demand for a study of the kind undertaken here. As an antiquarian, Scott was always interested in the relationship of the past to the present. Best known for his historical poems and novels, his prolific output over almost four decades (I795-1832) and across genres of poetry in 
translation, ballad collection, original short and long poetry, verse drama, prose fiction, literary journalism, letters and personal record keeping constitutes one of the nineteenth century's most significant critical enquiries into a nation's environmental history. Walter Scott and the Greening of Scotland provides an overdue exploration of that enquiry, critiquing Scott's writing specifically from an environmental perspective. The book accounts for an immediate and local, as well as more expansive, understanding of the history of the land and its significance to the people who live on it. My chapters investigate Scott's use of language and natural science, tracing the impact of his environmentalism across national literary boundaries. In doing so, they respond to a timeliness that is present both in his writing and in environmental literary studies now. As well as paying attention to global climate change and the need for detailed studies of literature's role in making public the events that contributed to that situation, any enquiry of this kind needs to address matters of environmental justice and arguments about the Anthropocene as an epoch in which the whole earth has been altered by human activity. This is a study, moreover, that begins with a focus on the earth in the form of soil and ends by looking through the sky to the stars. Then there is the temporal matter of Scott's mature works reaching their bicentenary. Those anniversaries invite a reappraisal of Scott's importance, 200 and more years on from the moment when enthusiastic, engaged readers first took notice of his writing.

The aim of my book, then, is to reassess Walter Scott's writing from the new, more environmental perspective that I have begun outlining. In the course of my investigations, the chapters that follow enter into in a dialogue with twenty-first-century ecocriticism. The book asks how Scott's poems, novels and prose non-fiction represent a history of local environmental change, assessing the immediacy of that writing against temporally longer and geographically wider-reaching effects. Scott is known for his interest in ballads and metrical romances that mapped human histories, as well as for his historical novels. Georg Lukács' The Historical Novel was the pioneering study of that socio-historical focus on his work, and still has plenty of relevance. ${ }^{4}$ Since Lukács, the expansive volume of critical enquiry into Scott's groundbreaking representations of people and the events that shaped their lives has brought a variety of theoretical and critical perspectives to bear on his work. Yet no booklength study has looked at his equivalent contribution to the memory mapping of the natural world. Green zones emerge in his writing, attending in main texts and in substantial bodies of notes as well as in 
introductory essays to several centuries of change in land use. Scott addressed issues ranging from the drainage of marshes in the former 'debatable' lands of the Borders to the increase in monocultural pasturage for sheep farming across Scotland; and from deforestation and reforestation using native rather than imported species to the effects on the land of depopulation through mass migration (effectively, an exchange with Canada of people for trees). His storytelling depends upon shifting riparian environments, and brought into print the folklore of mountain, island, lake and seashore communities.

The essential ecological framework in which Scott situated his intellectual and emotional life is captured in a brief statement that he made to Washington Irving, that 'if I did not see the heather, at least once a-year, I think I should die? ? $^{5}$ The connection here of heather with sight, thought and remaining alive invites closer enquiry. While often associated with the Highlands, common heather, Calluna vulgaris grows prolifically in the acidic soils of heathland, bogs and moorland throughout Scotland. Scott knew it not least from the childhood years that he spent at his grandfather's Sandyknowe farm in Roxburghshire and, in his adult life, from the Eildon Hills that he could see from his Abbotsford estate. Historically controlled by burning in the interest of farming and field sports, heather is a hardy plant that is resistant to the effects of grazing where more succulent plants are eaten by sheep, cattle and horses. If it disappears, the reason is usually mechanical removal or interference with the soil through use of fertilizers. Heather also grows in some mixed woodland where the soil is acidic, along with Scots pine and oak. These ecological contexts with their communities of herbaceous plants, trees and habitats emerge as the heartbeat of Scott's writing about his nation's land. His affiliation as a Romantic writer for whom wandering solitary characters and an imaginative contemplation of the natural world are as important as for Wordsworth, can be seen in another declaration of his affection for the Scottish Borders that he made to Irving, about his preferred home from his childhood until his death in I 832: 'It may be partiality, but to my eye, these grey hills and all this wild border country have beauties peculiar to themselves. I like the very nakedness of the land; it has something bold, and stern, and solitary about it. ${ }^{6}$

Scott and Wordsworth are often read for their contrastive contribution to Romantic poetry, mainly because of their differing styles when it came to balancing narrative, lyric and reflective content. However, Stephen Gill has shown that their thirty-year friendship was actually sympathetic on matters that connect the environment, a spirit of place and experiential 
composition. ${ }^{7}$ Gill makes his case with reference to four poems by Wordsworth, each of which concerns a river that Scott introduced him to as a literary subject. Those poems are 'Yarrow Unvisited' (I 803), written after the poet and his sister Dorothy had met Scott in Melrose and Jedburgh, 'Yarrow Visited' (I8I4), 'Yarrow Revisited' (I835) and 'Musings Near Aquapendente' (I 842), the latter three of which connect both poets with the river Yarrow as a muse. Looking back to Irving's anecdotes, this first of several comparisons that I shall make between Scott and Wordsworth established their shared contemplative association of solitariness with an entire human and non-human environment.

Farmland, forests, rivers and shorelines are Scottish environments where man-made changes can quickly be seen and where the impact on cultural practices is most rapidly felt, not least because of demographic alteration. By the late eighteenth century, urban drift had led to a depopulation of the Borders that Scott had personally witnessed. By way of environmental history, Scott's poetry and his historical fiction address shifts in the ecologies of these places that took place over many centuries. Species loss in flora and fauna is shown to occur alongside the reduction in human populations. In his personal life, Scott's interests in farming, forestry and fishing are further recorded in letters, essays, journals and reports. His childhood years were divided between the city and country. He lived for part of the year in Edinburgh and the rest of the time mainly stayed at his grandfather's farm, as mentioned above, which was located at the small village of Smailholm between Melrose and Kelso. During that time, he developed the deep love of the natural environment and culture of the Borders that led to his collecting of ballads for his first major publication, Minstrelsy of the Scottish Border (I 802-1 803).

Walter Scott and the Greening of Scotland enquires into ways in which the nineteenth-century environmental imagination can help our understanding of the twenty-first-century global crisis. It does this by investigating a problem-laden history (beginning with Scott and his historical imagination, and very much still with us) shaped by conflicts of interest between business-oriented economies, local communities and their traditions, and the land itself. Climate change and pollution are issues about which Scott showed concern; for example, his letters pay regular attention to shifts in weather patterns and their effects on plants, animals and birds. Contamination of the soil and water was another of his concerns, developing out of his activities in farming, arboriculture and hunting. Fossil fuel consumption and its effects emerge as an area of interest extending beyond initial concerns about financial investment. Scott was one of the first 
people to appreciate the desirability of finding cleaner ways of producing carbon-based energy. I investigate later in this introduction the part he played as Chairman of the Edinburgh Oil and Gas Company, particularly in its competition against the Edinburgh Coal Gas Company to secure the contract for lighting the city of Edinburgh.

Walter Scott claimed to have planted more than a million trees. He also wrote passionately against a future in which industrial forestry would see large monoculture plantations of non-native species replacing old growth woodlands. Two of his articles for the Quarterly Review, published late in his life in 1827 and I 828 , critically examined economic definitions of 'waste land', influencing practice and policies in arboriculture across Britain. Another recollection of Washington Irving is that when the two men were walking together at Leith port in Edinburgh, Scott responded to seeing a huge, imported white pine log by talking about the tree's life and ecological role in the forests of North America: the transatlantic lumber trade in which emigrant Scots, in effect, were exchanged for cargoes of timber was a catalyst for his environmental imagination. At that time, deforestation in North America was interfering with complex ecologies that had evolved over millennia. Clear-cuts were already initiating climate change. In Chapter 5, I discuss Scott's interest on the one hand in the loss of people through emigration to North America and on the other to his concern over the importation (mostly from Canada, on returning ships) of non-native tree species to replace what had been lost over hundreds of years of deforestation in Scotland for the sake of both agriculture and pasturage.

Meanwhile, everyday people in Scott's novels comment on the effects of a decline in the number of salmon in Scotland's rivers, due to over-netting in estuaries. Fictional fisherwomen haggle over the pricing of common and rarer species (i.e. herring, haddock, lumpfish, John Dory and turbot). People lose their livelihoods. Some lose their lives. Modern breeds of cattle are compared with extinct species whose larger bones had been found preserved in peat marshes. Descriptions in Scott's novels even contributed to breed standards for some types of working dog, as in the case of the 'mustard (sandy/brown) and pepper (blue/ grey)' Dandy Dinmont Terriers that feature in Guy Mannering. ${ }^{8}$ Fruit trees and pasture for livestock are watered by streams that flow through sites of massacre, transferring minerals and organic compounds along the food chain. Wildflowers tenuously cling to existence at the edge of trails, near to the spot where, according to legend, the thirteenth-century Scottish poet Thomas of Erceldoune, known as the Rhymer, was taken on a 
subterranean journey of discovery by an elf-woman. Stones accumulate deer hair, lichens and particles of soil that permeate their surface and reveal a still-unfolding history beyond the human lives memorialized in their inscriptions: the unchanging solidity of rock is brought into question by that organic process of transformation. These stories, sometimes reclaimed, were told, retold and elaborated by Scott.

Environmental justice, with the attention that it draws to the allocation of damaged or less productive land to the poorest and most endangered people, is an issue in Scott's writing and its afterlife. Authors born in Scotland, who during the nineteenth century travelled to make new lives in North America, show how Scott influenced their ways of thinking about New World ecologies and people. Environmentalist John Muir attributed his own interest in storytelling and literary landscapes to being raised on Walter Scott's poems and novels (he was born at Dunbar, near Edinburgh). In the thin mountain soils of California's High Sierra, in the moraine of glaciers, and in cultural practices he encountered among people in the western United States and Alaska, Muir recalled the Scotland about which Scott had written. Towards the close of the nineteenth century, Robert Louis Stevenson revisited Scott's Master of Ravenswood, who in The Bride of Lammermoor had died in quicksand along the Lothian coast, transplanting the cultural legacy of Scottish Romanticism into the frozen winter soil of upstate New York forests. In Stevenson's The Master of Ballantrae, an inscribed stone commemorates the burial place of émigré James Durie, the eponymous Master, whose death results from a failure of environmental and cultural understanding. The present book will trace these and many other developments that began with Scott's environmental imagination, analysing and interpreting their implications for literary and environmental history.

Rob Nixon's environmental justice and land ethics theory in Slow Violence and the Environmentalism of the Poor, arguing that the First World cannot easily see, let alone comprehend the effects of 'slow time' catastrophes lived by the world's poorest people in degraded environments, frames my enquiries into Scott's treatment of crises affecting rural communities, such as damage to soil structures, the depletion of resources and alterations to water supply. Nixon explores violence that 'occurs gradually and out of sight, a violence of delayed destruction that is dispersed across time and space, an attritional violence that is typically not viewed as violence at all'. His insistence that attention be given to the 'calamitous repercussions' of gradual damage is helpful in understanding the impact of the human as well as the non-human environmental justice issues that arise 
in Scott's writing. ${ }^{9}$ As an author and a sheriff, Scott was always interested in the ways in which matters of justice and legality were connected with storytelling and its representations of time. Most of the stories that arise in his books involve aggression in one form or another. Where periods of human conflict and acts of ecologically felt violence are concerned, his work was all published during three-and-a-half particularly turbulent decades. Those years included the major international wars of the Napoleonic period, the development of radical new farming technologies during what became known as the agricultural revolution, and the globally expansive, militarily backed, thrust of the British Empire. On their own and more so in combination, these contexts all involve an acceleration of the pace at which life was experienced. As a consequence, older lifestyles based around natural rhythms and longstanding conditions of the land became increasingly conceptualized as wasteful; of time, opportunity, land, resources and money. Associating slower, more traditional lifestyles with a past that could be remembered nostalgically and incorporated into a narrative of 'improvement' created an alternative environmental epistemology based in the laissez-faire economics proposed by Enlightenment political economists including Adam Smith. Land, rivers and coastal waters were understood as material resources with exploitable potential on the one hand, and as 'legacy' landscapes and seascapes in need of preservation because of their contribution to a marketable national character on the other. ${ }^{\text {IO }}$ In reality, these attitudes resulted in conflict because habitats and the ecosystems they support could not easily fit both models. Hugh MacDiarmid would later write in his poem On a Raised Beach, originally published in his 1934 collection Stony Limits and Other Poems, that 'impatience is a poor qualification for immortality.' ${ }^{\text {II }}$

The ballads in Minstrelsy of the Scottish Border and long narrative poems including The Lay of the Last Minstrel and The Lady of the Lake question the ethics of improvement through their dependence on a collective memory that is associated with specific components in local ecologies. Those local ecologies are frequently seen to be fragile, with tropes of memory giving rise to a literary activism that draws attention to losses resulting from choices in land management. A ballad from Scott's Minstrelsy such as 'The Flowers of the Forest', in which imagery of flora is both actual and a metonymic commemoration of war dead, shows how ecologically dependent elegiac and historical narratives can be. Timothy Morton has shown that, as a genre, elegy is overwhelmingly environmental, because its techniques depend upon echoes of grief that resound between the human mourner and a non-human world. ${ }^{\mathrm{I} 2}$ At the same 
time, ecologies themselves tend to be elegiac because they so often bear witness to loss and decline in the natural world including the death of species. As Fiona Stafford points out, the Border ballads of the Minstrelsy, along with Scott's accompanying framework of introductory essays and notes, use the conventions of elegy to impress on readers that the object of lament has gone forever, and that life necessarily moves on. ${ }^{13}$ Stafford's important study looks at the sociological function of the ballads for Scott as he mediated to readers the cultural history of the Borders. Where the non-human foil for mourning or nostalgia that is invoked by elegy has also disappeared, what is left is a more problematic space of absence in which literature continues repeating the cycle of grief. 'The Flowers of the Forest', which is discussed in more detail in Chapter 3, is an example especially because of the second part that Scott added to the original ballad. Scott's The Antiquary, The Bride of Lammermoor, The Heart of Mid-Lothian and Redgauntlet are novels that further address problems of conflict in the use and aesthetic values associated with farmed coastal environments, rivers, estuaries and the sea. His letters and journals show how concerns about the preservation of memory and the land, which inform his poetry and prose fiction, influenced his management practices on his own estate, as well as informing his criticism of the stewardship of other landowners. One other question that arises is whether Scott's experience as a landowner, and one who spent his last years living with insolvency, enabled him fully to understand the problems faced by Scotland's poorer inhabitants in their daily relationships with the non-human world.

\section{Land Ethics}

Walter Scott has probably contributed more than any writer to perceptions of Scotland as a land of mountains, moorlands, heather, mists and water. But does his writing look beyond such a stereotypical terrain to demonstrate an agency arising not just from the human histories that form the basis for his plots, but also from the land itself? To what extent did he write about woodlands, rivers, soil and mountains as phenomena existing outside the control of, or manifesting resistance to, the interventions of modern society? Is there anything in his poetry and fiction that advocates or supports what we might call a land ethic? I refer here to something understood as 'a limitation on freedom of action in the struggle for existence', specifically involving humankind's 'relation to the land', as first proposed by Aldo Leopold in the late I940s. ${ }^{\text {I4 }}$ The relevance of Leopold's land ethic, published I I7 years after Scott's death, 
is its basis in something of primary importance to Scott: the necessary morality that informs the relationships of communities with the land and environment. For Leopold, a land ethic 'enlarges the boundaries of community to include soils, waters, plants and animals, or collectively: the land'. ${ }^{\text {Is }}$ He proposes responsible management (not the exclusion of humans) in which respect and sympathy exist among people for everything that composes the ecology of an area. ${ }^{16}$ Scott understood human relationships with the land in ways that valued it and its biotic communities, to use another of Leopold's terms, beyond merely its potential to generate economic wealth. His writing makes the case time and again for a sympathetic and collectively responsible approach by people to place. Whether he evinces a philosophy of land relations that is willing to subordinate human interests that are mostly economically driven to the survival of vulnerable non-human elements is a more complex matter requiring further investigation.

As a plantsman, ecologist, antiquarian, lawyer and author, Scott mediated and drew attention to matters of environmental justice and land ethics, more than a century before Leopold's 'Land Ethic' essay, which concludes A Sand County Almanac, and Sketches Here and There (1949), established the case for that latter term. Leopold's interest in a land ethic began during his years as a young adult after college while he was working as a ranger in the Apache and Carson National Forests in Eastern Arizona and New Mexico. I shall return to Leopold in more detail later in this introduction. But for now, it is relevant to observe that his early job as a ranger required him to eliminate as many wolves as possible in the interest of protecting deer for hunting. A conversation between two characters in Scott's novel Redgauntlet (I 824 ) begins by comparing the prolonged slow violence suffered by sheep as a result of their being raised as stock with the sudden spectacle of an attack on them by a wild predator such as a wolf:

'Were a wolf, he said, 'to come even now upon yonder flocks, they would crowd for protection, doubtless, around the shepherd and his dogs; yet they are bitten and harassed daily by the one, shorn, and finally killed and eaten by the other'. ${ }^{17}$

The debate develops into a further consideration of animal rights and farming practice alongside the ethics of 'sports, as they are called, which have the sufferings of animals for their end and object ... making their protected agony a principle of delight and enjoyment'. The same character, Quaker fisheries entrepreneur Joshua Geddes, later comments on the corruption of animal nature by men in the cause of dogfighting: 'men 
arm their bull-dogs with spiked collars, and their game-cocks with steel spurs, to aid them in fight, so they corrupt, by education, the best and mildest natures, until fortitude and spirit become stubbornness and ferocity'. Returning to wolves, they probably became extinct in Scotland during the middle of the eighteenth century although the last officially recorded killing was in I680, ironically during a period of intensive religious and political persecution that itself became known as the Killing Time, in which several of Scott's works are set. ${ }^{18}$ Scott, who enjoyed mutton and was a keen hunter as well as a sheep farmer, expressed a sympathetic understanding for the quality of life of animals, birds and fish. That sympathy is explainable through David Hume's Scottish Enlightenment theory of human understanding. For Scott as for Hume the imagination of the sympathizer works through a process of personal experience, observation and associationism by which the passions transcend the barrier to knowledge that arises from otherness, inducing a sense of shared feeling that itself becomes a form of knowledge. Moreover, Scott's case for humankind's ethical awareness and moral understanding of its place within a region's and the earth's biosystems doesn't end with hunting and farming, but extends to the damage caused to river and estuarine environments by the exploitation of hydrological resources including commercial overfishing. These issues are explored in greater detail in the chapters that follow. In summary, this book is interested in showing how Scott used poetry and prose to treat conflicts of interest affecting entire ecosystems.

Other questions arise: was Scott mostly concerned to encourage the idea of a Romantic, largely pastoral but otherwise wild Scotland, nostalgic for a time when a mainly rural society had closer ties to the land than to cities, such as would support the maintenance of a strong local as well as national communal identity? Does his representation of environmental issues including concerns about state and commercially motivated deforestation, planting policies, changes in land use and his own intervention to preserve stocks of fish in rivers, provide any effective counterpoint to identity politics that are based in an urban-centred, capital-driven political economy? These are pertinent questions for readers in the twenty-first century, when it is difficult to imagine a Scotland unaffected by climate change, acid rain, habitat and species loss, and without debates about how to balance an economy based upon exploitable resources (oil and gas, in particular) with the demands for access made by the tourist industry and the lobby for conservation. They are also questions that draw attention to the scale and impact of Scott's contribution to the environmental 
historiography of Scotland, as a nation always needing to mediate and address the effects of changing land use.

As a self-styled Borders 'minstrel', 'Wizard of the North', and latter-day 'Rhymer', Scott was a storyteller of the environment as much as a writer about social history. ${ }^{19}$ All three sobriquets have literary geographical roots in which words derive at least part of their power from an uncanny strangeness associated with the soil: for example, from the Borders lowlands and moorland in which lie buried medieval poets, popular heroes and travellers who returned from Italy and the Middle East with knowledge of alchemy and occult science gained during foreign travel. His ecological concerns are written into ballads, long narrative poems, fiction and verse dramas, but many are also incorporated within letters or essays published in periodicals. Others are found in his journals, notebooks and in contributions to the proceedings of associations such as the Tweed Commissioners, founded in 1805 with the aim of implementing managed stewardship of the overall ecology of the River Tweed. Scott's first long poem, The Lay of the Last Minstrel (1805) connects everything that he writes afterwards with Scotland's rivers, through a concluding ecological analogy that links poetry with the sound of naturally flowing water. The minstrel of the poem's title refuses an invitation to live in comfort in Newark castle, choosing instead to spend his last days beside the river Yarrow, a tributary of the Tweed. The poem ends with a merging of the living sound of the running river with the dying minstrel's song: 'And Yarrow, as he roll'd along / Bore burden to the Minstrel's song'. ${ }^{20}$ The idea that sounds from the land (a river) synthesize with those from literature (the song of the poet) in an ongoing flow of ideas might well be interpreted as part of a conventional ideology of national identity: but an ecologically responsible approach to the non-human environment is necessary if cultural memory and ongoing literary creativity are to remain possible.

That Scott was caught in some contradiction by today's standards when it comes to land ethics cannot be ignored. He contributed to the rise in the early nineteenth century of Scotland's carbon economy through involvement in the oil and coal industries. That episode, already briefly alluded to, tells a story of Scott's interest in the conversion of fossil fuels into sources of energy, albeit with concern for economic viability alongside some awareness of environmental responsibility. One of the first people to use gas central heating in his home, in I 823 Scott also literally bought into what he described as the 'mania of the day' by taking shares in the Edinburgh Oil and Gas Light Company, one purpose of which was to illumine the city of Edinburgh with gas manufactured from whale oil. 
Within a year he was the company's Chairman. The main rival for the Edinburgh lighting contract was the Edinburgh Coal Gas Company, which was manufacturing its product more cheaply from coal. Meanwhile, the location of the Oil and Gas Light Company's production works at Tanfield, Inverleith, was next to the Experimental Garden of the Caledonian Horticultural Society (now the Edinburgh Royal Botanic Garden) and was itself fuelling an incendiary environmental controversy. Correspondence and pamphlets, including a petition that Scott physically delivered to Parliament in I 827 regarding that controversy and its part in the city of Edinburgh lighting contact, shows Scott to be aware of damage to the environment arising from industrial pollution. His proposed solution was recyclable waste products that offered an economic benefit in the process of land improvement. Let us look in more detail at that episode.

In a bid to compete with its rival, Scott's company petitioned Parliament to be allowed to manufacture coal gas, using a different process from the Coal Gas Company. A group of botanical scientists from Edinburgh University mounted a counter-argument that, in addition to adverse effects on human health in the locality, formerly healthy tree species had suffered significant damage to their foliage due to emissions from the gas plants close to the Experimental Garden's own old city and new, enlarged Tanfield sites. First the oil gas distillation plant and then the proposed transfer from oil lamps to coal gas production for lighting the city generated complaints about air pollution that was affecting health in residential areas, as well as damaging trees and plants at the Experimental Garden. Farther into the city, at New Street (adjacent to what is now Waverley Railway Station), the Coal Gas Company was producing a greater level of pollution, with liquid ammonia waste being discharged into waterways and air particles causing respiratory problems. Although this problem wasn't specifically connected with acid precipitation, Scott took up the matter of relative levels of air pollution and their effects, along with the contamination of waterways in his argument about the differing processes of producing gas. He attempted to persuade Parliament to allow the Oil and Gas Light Company to use its improved method of production. Coal was already understood to be a dirtier fuel than oil, as he pointed out in his statement supporting the Edinburgh New Gas-Light Bill in $1827 .^{21}$

By I 826, most streets in the New Town, Leith Walk and Lothian Road were already being lit by coal gas lamps. Scott's petition argued in response to criticism that the Oil and Gas Light Company was managing lime, tar and ammonia disposal in more environmentally responsible ways, using its 
dry lime by-product for agricultural manure and taking more secure measures than the Coal Gas Company to avoid smells and gas escape. ${ }^{22}$ By contrast, the Coal Gas Company was a major polluter that disposed of its liquid lime effluent directly into common drains and rivers. Despite the arguments, Scott's championing of the Oil and Gas Light Company was unsuccessful. The Edinburgh Coal Gas Company secured the lighting contract with their cheaper production process. Scott's own venture failed financially, and the Oil and Gas Light Company was eventually bought by its rivals. ${ }^{23}$ However, while the separate ethical issues about environmental responsibility and whaling were not recognized at the time, Scott's argument that oil gas is cleaner to produce is remarkable, as is his writing about the benefit of recyclable by-products. Scott lamented in a letter to John Gibson Jr. in January I 828 that he would never see a financial return on his investment. ${ }^{24} \mathrm{He}$ also recorded in his Journal on 4 June I 828 , 'By the way, we have lost our Coal Gas Bill. Sorry for it, but I can't cry'. During the controversy, the case for oil as less wasteful of energy than coal was supported by the young thermo- and electrochemist Michael Faraday. ${ }^{25}$

Meanwhile, in I 825, Scott had staked a substantial I, 500 pounds in the development of a railway that would bring coal and lime to Abbotsford, not least to supply cheaper coal for the gas plant that he was using to light and heat his home, but also in order that lime from the process could be used as fertilizer for the soil of the estate on which he claimed to have planted his million trees. Planting trees as an offset to the footprint of carbon fuel consumption is a trade-off in our own time that controversially gestures towards a land ethic. Scott could not have known that he was living during the emergence of a carbon-driven Anthropocene epoch, associated with the rise of technology deriving from chemist and engineer James Watt's improvements to the steam engine in the 1760 s and 1770 s. $^{26}$ The Grangemouth oil refinery on the banks of the Forth and twenty-firstcentury arguments over fracking for shale gas in Edinburgh, the Lothians and other Lowland areas of Scotland seem a relatively short step from the oil gas and coal gas production that Scott helped to finance. ${ }^{27}$ However, Scott's writing does show him to have been concerned two centuries ago about forms of violence towards the land and towards society resulting from economically driven changes in energy policies and farming practice.

\section{Revising Aesthetics}

As mentioned earlier, most scholarship on Scott's storytelling has prioritized his treatment of culture and events from human history. Criticism 
has explored his development of literary genres from early translations of poems by Goethe and Burger, to the ballad anthology Minstrelsy of the Scottish Border, to the three-volume novel. Studies of his use of narrative methods ranging from framing devices, voice, language, constructions of character and techniques such as the entrelacement of storylines, have shown how he developed original ways of writing from older points of departure, bringing together British and European literature from high and popular cultural sources. Where Scott focused on the landscape, critical enquiry has investigated his treatment of historical memory and place in an anthropocentric social politics. The aesthetics of that approach are framed by a combination of Edmund Burke's A Philosophical Enquiry into the Origin of our Ideas of the Sublime and Beautiful (1757), Uvedale Price's Essay on the Picturesque, As Compared with the Sublime and the Beautiful (I794) and William Gilpin's many essays on painting and picturesque landscapes (I768-I809), together with numerous other works that develop and critique those theories. Since Scott was educated in the schools of the Scottish Enlightenment and wrote throughout the Romantic period, such a context would be expected. However, his acceptance of parts of Burke's aesthetic philosophy alongside an idiosyncratic alteration of the standard viewpoint implied in the 'picturesque in scenery' repays deeper enquiry.

Burke's argument that the land has an innate capacity to generate feelings of fear, awe and pleasure is given a degree of counterpoint in Price and Gilpin's recourse to a visual language of knowledge based in a recognition of how land can be understood through an appreciation of art. Scott's copy of Burke's Philosophical Enquiry contains a dedication dated I789. He was then aged eighteen. Scott also owned an I8 Io copy of Price's Essay on the Picturesque ${ }^{28}$ and several books of socio-geographical tourism by Thomas Pennant, including a I 790 fifth edition of his $A$ Tour in Scotland, and Voyage to the Hebrides in $1769 .{ }^{29}$ In a letter to Joanna Baillie dated March I 813 , eighteen months before he published Waverley (I 8 I 4), he attributes to Price's theories his taking of land at Abbotsford out of cereal farming for the purpose of planting trees: 'many of our jog-trot Country-men would revolt at being made my instrument in sacrificing good corn land to the visions of Mr. Price's theory'. ${ }^{30}$

While Scott agreed with Price's argument for a moral value to landscape that can override economic profit, his response to Pennant was more complex. An example of how his storytelling became a vehicle for a critique of the picturesque Highland tourism that Pennant inspired can be seen in the episode in chapter 22 of Waverley (I 8 I 4), titled 'Highland Minstrelsy', 


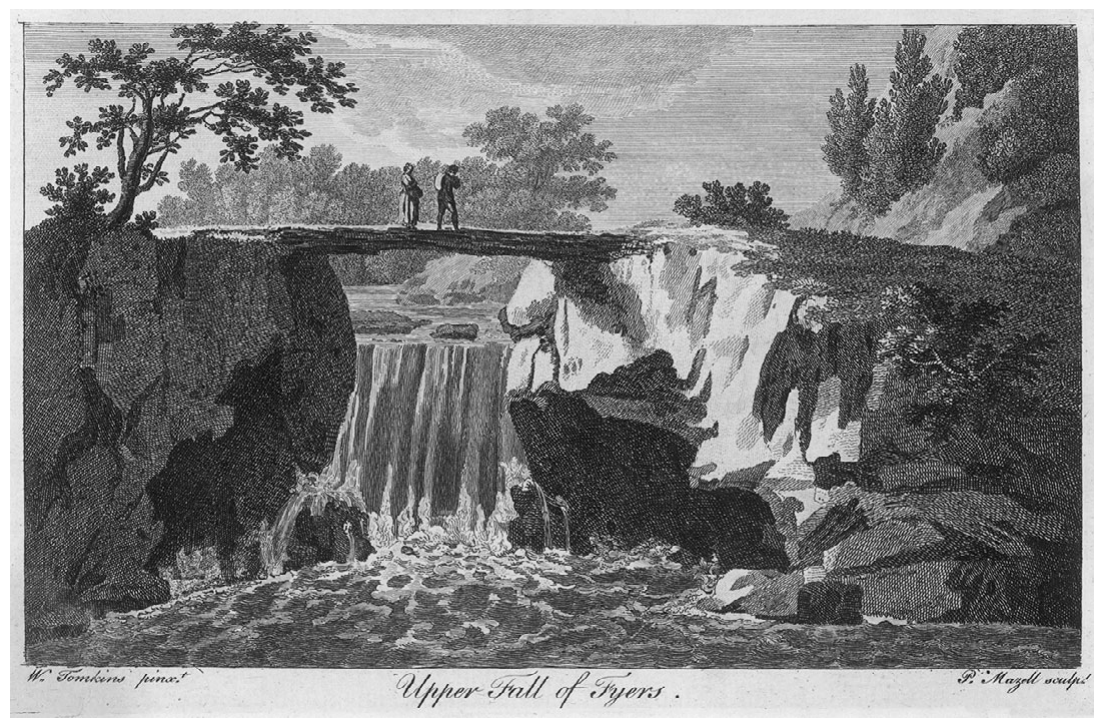

Figure I.I Engraved illustration, 'Upper Fall of Fyers', from Thomas Pennant's

Tour of Scotland and Voyage to the Hebrides (selected editions I765 onward).

The scene sets a precedent for an episode in Scott's Waverley. Published with permission from Chronicle / Alamy. (C) Alamy

where Flora Mac-Ivor literally takes Edward Waverley's breath away by waving to him while standing on the 'perilous pass' of a pine-tree bridge, I 50 feet over a rocky chasm. In a moment of sensibility, Waverley is 'unable, from the sense of dizziness which her situation conveyed, to return the salute. ${ }^{3 \text { I }}$ The scene demonstrates Burke's theory that the Sublime is a force capable of producing psychological terror and physical paralysis in a viewer who can enjoy both sensations only by remaining at a sufficient distance. At the same time, Scott's levity interleaves a comic tone that tempers any realistic threat to life into a perspective that readers would recognize as more consistent with the picturesque: the spectacle looks like a landscape painting or an illustration from a book. Scott's edition of Pennant's Tour contains a description and accompanying illustration of just such a bridge at the Fall of Fyers in the Highlands, made famous by Robert Burns' 1787 poem 'The Falls of the Fyers' (Figure I.I). In the illustration, a woman and a man stand on a narrow pine bridge, while the narrative describes 'a true Alpine bridge of the bodies of trees covered with sods, from whose middle is an awful view of the water roaring beneath'. ${ }^{32}$ Landscape painter Thomas Walmsley painted the falls in I8Io using a 
similar composition, with print copies sold through commercial printmakers (see cover image). ${ }^{33}$

Edward Waverley's swoon at Flora's apparently dangerous behaviour is set in 1745 , twelve years before Burke's Enquiry would have explained his condition. He reverses eighteenth-century gendered behavioural and medical conventions in which women, rather than men, would be expected to display such heightened physical signs of fear at the sight of a dangerous situation. To that end, Scott anticipates, and satirically derogates, the 'man of feeling' who emerged from the culture of sensibility towards the turn of the nineteenth century. A third of the way into the novel, Waverley's incapacity falls notably short of the masculine vigour that the rugged country of the Highlands might be expected to inspire. Unable to do anything to render Flora's situation safer than he believes it to be, and about to join the losing side of an armed conflict that ends with the 1746 massacre at Culloden, he is a failure as a 'natural' soldier and protective hero.

There is more to explore in this episode, though, in terms of the function of the land in question beyond its aesthetic agency. Waverley is a tourist, not a Highlander. He views the land north of the Highland geological fault from a cultural as well as a physical distance, perceiving it to be simultaneously magnificent and vulnerable. Informed by topographical and gothic reading in his uncle's library and disposed to think in categories of the sublime and the beautiful, his reaction to Flora's situation derives from affect rather than from any cultural understanding of how Highland people relate to the land on which they live. Moreover, Waverley's tendency towards imaginative misunderstanding has already been ironized when he surmised that Donald Bean Lean might live in a cave following the latter's mischievous welcome of him 'to my house. ${ }^{34}$ The bridge on which Flora stands, barely three-feet in width and made of two Scots pine trees, is familiar and entirely safe from her close-up perspective. She is firmly in touch with the trees, rocks, cataracts and expansive skies; so much so that rather than being suspended in air as Waverley fancifully imagines, she is securely part of a connected ecology at the top of which she stands. While Waverley displays a less-than-masculine misunderstanding of a scene viewed like a painting or book illustration, Flora is part of the land itself. Even her name implies a natural system, rooted in sympathy with plants. While pine supports her, the surrounding trees are identified as birch, oak and hazel with a scattering of yew, representing the main species that colonized the region after the thawing of the post-Pleistocene-glaciation tundra. ${ }^{35}$ Scott's 'Highland Minstrelsy' chapter grounds Flora Mac-Ivor's story in a complex system that comprises 
geology (rocks), botany (pine trees and flowers) and the elements (air and water). Moreover, her gestural wave draws attention to a natural harmony that establishes a point of contrast with the ending of Waverley where, as I shall show in later analysis of the novel in my third chapter, an act of violent intervention attempts to terminate the land's capacity for revealing stories. That violence against the land centres on the removal of ancient trees, a subsequent levelling of land contours and the planting of a monoculture of grass at Tully-Veolan. The re-landscaping, which extends deep below the surface of the soil and affects everything that lives in and grows from it, tells its own story of how the Highlands as the managed 'estate' of modern Scotland was transformed into sheep pasture from an older, mixed system of land use dominated by cattle husbandry and wild game hunting. That process is ultimately identified by Scott as an act of violence against the land as well as an act of cultural erasure. Moreover, the abrupt discontinuities of Davie Gellatley's consequential forgetting of his old songs and Flora Mac-Ivor's vows of silence represent an enforced muteness that bleakly contrasts with the onwardly rolling music of the Yarrow that concludes The Lay of the Last Minstrel, and the 'brawling' mountain rivulet 'heard among the stones or in the clefts of the rock that occasionally interrupted its course' that gives 'life and animation' to a different landscape of massacre and remembrance in The Tale of Old Mortality (I8I6). In order to enjoy the sight of Flora at the cataract, Waverley must come to his 'senses'. He must defer to a Romantic myth driven by picturesque aesthetics that underpins the politics of creating a desirable pastoral out of a wild and threatening wasteland.

Scott's combination of adventure and comedy in 'Highland Minstrelsy' accords with his dislike of Pennant's representation of Highlanders as barbarians whose behaviour was in keeping with the savagery of the land. He mentioned that matter in a late letter to Donald Gregory on 17 July I 83I, writing that he had 'been shocked at the anathema [Pennant] has pronounced' on the Clan MacGregor, in particular, and had 'tried my best to laugh the world, the southern world at least, out of these absurd prejudices'. ${ }^{36} \mathrm{He}$ adds that, on the grounds of hereditary poetry rooted in the soil, 'the border Minstrels made a man of me'.

Changes in land use had altered the appearance of much of Scotland during the second half of the eighteenth century, due to the agricultural revolution and economic pressures that affected the Highlands in particular. These had been recorded and investigated before Scott began writing Waverley in 1808 , but sufficiently recently to influence that novel. The most comprehensive enquiry was John Sinclair's twenty-one volume 
Statistical Account of Scotland, published between I79I and I799, which included descriptions of every parish. Sinclair's survey, with its reports commissioned from local contributors, tells its own story of the decline of cattle farming in the Borders and Highlands, and particularly of the loss of older native breeds of cattle along with the rise in sheep numbers. Scott's fiction addresses those changes in ways that respond to Sinclair's manner as a storyteller. In The Heart of Mid-Lothian (I 8 I 8), part of the Tales of My Landlord, Second Series, the narrator, Jedediah Cleishbotham, repeatedly refers to the Duke of Argyll's contributions to animal husbandry in the earliest years of the agricultural revolution. His account is at least a twicetold tale, since the conceit of Scott's frame narrative is that it has been filtered through the papers of fictional schoolmaster and clerk, Peter Pattieson, who in turn had heard the details from the landlord of a local inn. The layered narrative and distancing of an historical setting in the second and third decades of the eighteenth century works similarly to the aesthetics of the sublime and picturesque already mentioned. But The Heart of Mid-Lothian's treatment of human tragedy and misfortune is packed with a different kind of detail that relates to land use. Again midway through the novel, a letter from Jeannie Deans to her father anxiously comments on Argyll's introduction of Devonshire dairy cattle in place of the older native Ayrshire breed. Jeannie expresses her affection for the native cattle and for the traditional Dunlop cheese made from their milk. Her father later becomes the Duke's cowman. A parenthetical narrative insertion into her letter refers to an official report: 'Here follows some observations respecting the breed of cattle, and the produce of the dairy which it is our intention to forward to the Board of Agriculture'. ${ }^{37}$ Many rural readers and landowners from Scott's own time would have understood the implication of that foreshortened note of intent. Jedediah Cleishbotham has already just said of the letter that it is too long altogether ... so we only give a few extracts'.$^{38}$ Scott is likely here satirizing the length of agricultural reports such as Sinclair's - the kind that George Knightley and Robert Martin discuss in Jane Austen's Emma (I8I 5 ). Indeed, he remarked that Sinclair could be tiresome because of his obsession with detail. ${ }^{39}$ The references to cattle and farming practices continue throughout The Heart of Mid-Lothian in a dialogue about the agricultural revolution that forms an aside to the main story, mediating between custom and innovation.

The Board of Agriculture and Improvement perhaps needs some explanation. Established in London by Royal Charter in I793, with the intention of producing a full survey of the parishes of England in the style of the 
Scottish Statistical Account, its founder and President until I 798 was none other than the editor of the Scottish survey, John Sinclair. While the English survey was never compiled, the reports that Sinclair had sent and continued to send from Scotland to the Board provide a detailed account of changing farming practices north of the border. Sinclair's edited twovolume General Report of the Agricultural State, and Political Circumstances, of Scotland, produced for the Board and published in Edinburgh and London in I 8 I 4, contains sections about climate, rivers, trees and livestock farming. The volumes include some direct storytelling, while their overall narrative builds into a saga of rural Scotland. The section on trees includes a brief history of the HMS Glenmore, an 800-ton frigate built in I 796 entirely of Scots pine, a species that Sinclair notes to be exceptionally valuable for its compact and durable wood. ${ }^{40}$ The Glenmore survived service in the Far East, Americas and Napoleonic wars and was eventually sold into merchant naval service in I8I4. Sinclair includes a passionate account of the value of the Scots pine generally in shipbuilding and architecture, which entirely accords with Scott's love of that species. $\mathrm{He}$ includes details of by-products from the wood including turpentine, lampblack and even the potential food value of the bark (for which he references Carl Linnaeus). In Scott's Tales of my Landlord, Third Series novel A Legend of the Wars of Montrose (I 8 I 8), Highlanders use blazing torches made of bog pine, with Scott adding 'this wood, found in the morasses, is so full of turpentine, that, when split and dried, it is frequently used in the Highlands instead of candles'. ${ }^{4 \mathrm{I}}$

\section{Trees}

It is no secret that while writing poetry and novels alongside his work as a lawyer, journalist and public intellectual, Scott invested time, effort and money that he didn't sufficiently have in his passion for planting trees at Abbotsford. The move of house from Ashiestiel in I8I I involved his relocating downstream along the Tweed, close to Galashiels and Melrose, where the river was wider than at his previous, rented home. The new estate included half a mile of river frontage with flood meadows that lived up to their reputation. There were few trees. Scott wrote of the new property to his brother-in-law Charles Carpenter, 'it is very bleak at present having little to recommend it but the vicinity of the river', but adding 'the ground is well adapted by nature to grow wood'.$^{42}$ The story of Scott's growing of that wood and his passion for the Tweed reads like a ballad of love and near loss. The cost of planting trees without doubt 
contributed to his insolvency crisis of 1826 , after which he was able to remain living at Abbotsford on a life-rent but had to sell his Edinburgh house. Journals and letters comment on the unfolding arboricultural programme, but the most intimate and concentrated record of tree species and where they were planted, along with Scott's notes about their success or failure, is the unpublished manuscript journal in which he made entries between I 8 I 9 and I825, Sylva Abbotsfordiensis. The Sylva pays attention to soil types, aspect and local climate: sandy, wet, exposed or sheltered. Those accounts, combined with descriptions of water sources and notes on the competition between wildlife, domestic animals, wild plants and tree species, build a picture of the ecology of the estate as it was during six of the busiest years of Scott's planting activity.

As Alison Lumsden and Gerard Carruthers have argued, the 'Preface' to the Sylva indicates that it was probably intended to become a public document about land use and tree cultivation: Scott addresses an imagined reader using a conversational tone and concluding that he was writing 'at least to amuse myself and to interest those whose lot it may be to walk under the shade of the trees which I am now engaged in planting. ${ }^{43}$ The Sylva can indeed be read as a source of interesting stories that develop across the different parts of the estate, based in the experiments that Scott conducted, and linking arboriculture to the ecological and literary history of the region. His purchase of the 'Glen at Huntley Burn' and his description of 'The Rhymer's Glen' are cases in point. Both are connected by name and, even if only arbitrarily, by location with Thomas of Erceldoune, the Rhymer and archetypal Scottish poet of the old borders ballad, which Scott had extended by adding a third part for the 'Imitation of the Ancient Ballads' section of Minstrelsy of the Scottish Border in I803. Scott's entry in the Sylva on the Rhymer's Glen demonstrates the extent to which he combined a Romantic sensibility with a practical approach to livestock farming and cultivating trees:

A romantick glen with a rivulet wandering down amongst rocks with remains of natural wood and a quantity of underwood of different kinds. The timber-trees of the upper part were estimated to me at $£_{14}$, on account of the difficulty in clearing them out of the ravine.

In I 817-18 many full-grown plants of from six to ten feet high were planted in this glen but without inclosing. They have sufferd by the sheep as was to be expected but still live \& may thrive when cut over.

The glen has been inclosed this season I8I8-I9 and it is proposed to plant it up but so as to preserve its wild $\&$ natural character.

It was accordingly planted up in spring I8I9 and must succeed well. ${ }^{44}$ 
The Rhymer's Glen, located not far from the stone that then, as now, commemorates a location where Thomas just might have composed his verses underneath the fabled Eildon Tree, is an enigmatic presence. Writing to John Richardson (a mutual friend of Scott and Joanna Baillie) earlier in 1816 , shortly after he had bought the land, Scott referred to the glen, which he had named, as 'a strange and secluded ravine', in which 'thorn trees, hazels, guelder roses, willows and so forth' provided natural wood and underwood mentioned above. ${ }^{45}$ Describing it also in other sections, in terms of and with a perspective from the land that surrounds it, Scott seems to have wanted to preserve its sense of mystery. Near to the glen's entrance at Mar's Lea, Toftfield, oaks and larches are the main planted species growing in what Scott describes as an 'indifferent soil' that slopes to the east. He records that 'the hares have done much damage among the larches' ${ }^{46}$ The larches are not thriving. The soil is indifferent. Furthermore, at Ushers Stripe, 'a small stripe running south east from the south side of the Rhymer's Glen', ash and larches are 'choked by coarse grass' and the trees are 'bent', while 'a few sweet or Spanish Chestnuts' are just 'beginning to thrive'. North and west, and running to the bottom of the glen, more larches are strangled by coarse grass. In each of the instances just mentioned, tree species introduced to the area - planted ash, but also non-native larches and Spanish chestnuts ${ }^{47}$ - have had their growth curtailed by the quiet violence and resistance manifest in the aggressive action of hares, and tangled and coarse grass. It is as if the land were protesting against invasion.

If the Sylva tells part of the story of Scott's planting programme, it also reflects on the connection between Scottish literature and the land that is made by Scott in Minstrelsy of the Scottish Border (1802-1803). Partly an old, anonymous ballad, probably from the fifteenth century, and partly an improved fragment, 'Thomas the Rhymer' recalls a legend set in the late thirteenth century that, as Scott says in his note in the Minstrelsy, is mentioned in early Scottish literature in the fourteenth-century long narrative poem History of Wallace, by Henry the minstrel (Blind Harry), in Andrew Wynton's Chronicle and by John Barbour in The Brus. ${ }^{48}$ In these respects, 'Thomas the Rhymer' demonstrates the evolution of Scottish literature down through five centuries to Scott's own lifetime. Set in a particular, although legendary, location in the Borders - Huntlie Bank, ${ }^{49}$ near the Eildon Hills, not far from the village of Erceldoune and under the Eildon Tree - the ballad argues for a literary rootedness in place. Included in all editions of the Minstrelsy, 'Thomas the Rhymer' grounds the origins of Scottish literature in the material substance of the soil of a 
local community, in the country of the Borders more generally, and in the land of Scotland as a nation. The earth in the poem begins as a strange place, alien, primal, prior to and outside the socio-political structures of nationhood. It constitutes the deep history and material ecology on which Scotland is founded. Thomas must discover the nature of what lies beneath the tree and sustains its growth, before he can transcend the limitation of mere verse to become a truly inspirational poet. The soil is the catalyst for that process, symbolically and as a substance made of living and non-living organic particles, each with their own as well as an ecological history.

The first and older part of 'Thomas the Rhymer' is explained by Scott to be a composite of two source copies: one he gained from Anna Gordon, Mrs Brown of Aberdeen, but the other is described only as being 'obtained from a lady, residing not far from Erceldoun[e]'. ${ }^{\circ}$ While Anna Gordon's copy indicates the mobility of ballads through their transfer from one place to another, the second copy remains rooted where the poem was originally set. What is more, its source is enigmatic: 'a lady, residing not far from Erceldoune' uncannily suggests a character from the ballad itself, the 'Ladye' or Elf Queen whom Thomas encounters. It is that first, composite part of the ballad that I am interested in here. The ballad begins with the story of how Thomas came intimately to know the soil of the land through an encounter linked to a tree. The process is one of immersion, like a Scottish vernacular version of the classical literary trope of a visit to the underworld. Before his encounter, we know only that Thomas composed verses. Then, while sitting on Huntlie Bank beneath the Eildon Tree, he 'spies wi' his ee' a 'ferlie', or strange lady riding a horse. A supernatural creature whose 'skirt was o' the grass green silk', and, I argue, representing the land's compelling and magical strangeness, she carries him down under the surface of the soil, among the roots of the tree. Beguiling him, the Ladye sings 'Thomas, ye maun go wi' me', urging him to sing his rhymes:

\footnotetext{
'Harp and Carp, Thomas', she said;

'Harp and carp along wi' me:

And if ye dare to kiss my lips,

Sure of your bodie I will be'.

...

All underneath the Eildon Tree.
}

$$
(5-6,17-24)
$$

The Rhymer lives with the elf queen underground for seven years before returning to the surface. When he returns to the world of late 
thirteenth-century Scotland, his poetry has been transformed by this environmental version of a visit to the underworld: he is changed and his words now take the form of prophecy, involving wisdom as much as an ability to see the future.

'Thomas the Rhymer' is fundamental to the deep ecology of the Minstrelsy. The ballad tells a history of the land on which all of Scottish literature depends, putting that land first. Poetry comes afterwards. Dirt, like soil, as ecocritic Heather Sullivan has argued, is usually regarded as a 'less glamorous' substance. ${ }^{5 \mathrm{I}}$ The Rhymer's encounter with the 'ferlie', however, recognizes the earth precisely as entrancing matter: something that not only cannot be ignored, but that absolutely will not be resisted and that must not be forgotten. Ian Duncan, in his seminal study of realism in the Sottish novel, draws on Mary Douglas' definition of dirt as 'matter out of place' and 'an excess in the order of culture' to remind us that it is dirt's superfluity that ensures its visibility. For that reason, in its metonymic capacity dirt (along with soil and earth) binds aesthetics with reality. Duncan invokes the residue theory of Roland Barthes' 'reality effect'. ${ }^{52}$ Vitally for the Minstrelsy and for emerging literary ecologies, 'Thomas the Rhymer' functions as an archetypal poem that demonstrates the essential 'truthfulness' and enjoyable magic of a literally down-to-earth Scottish poetic tradition. The success of the ballad, which is evident in its endurance down through centuries, relies on the agency of the earth both as matter and symbol. Dirt theory is particularly helpful here because of its insistence on acknowledging the inseparability of soil and dirt on the one hand, with all those substances' homophonic negative associations, and earth on the other hand as a more positively imagined substance. Symbolically, vitally and materially the Eildon Tree is nourished and its form shaped as much by dirt and soil as by earth. The tree, with its roots in the soil and its branches above the poet, connects the human world with the material earth and with hidden histories. Beneath its canopy, and coming to know what normally remains unseen, the creative imagination is transformed into part of something more expansive in time and space than the temporally limited and changing world.

\section{Rivers}

By the time Scott published the Minstrelsy, he knew that not just the appearance, but also the substance of the soil of the Borders had been changed. An older, wooded terrain and substantial areas of wetland and treeless peat bogs had been, or were being, transformed into a landscape 
dominated and defined by pasture. Sheep farming changes the soil. The impacting caused by the animals' feet, their grazing habits and the mattlike roots of grass affect the water content and composition of the earth, which in turn defines everything that lives below the surface of the ground. Where lime was added to improve grass growth, in accordance with advice on Improvement during Scott's lifetime, the soil's $\mathrm{pH}$ became more alkaline, affecting biodiversity ranging from microbes to plants and all the species that depend on them. Burns or streams, increased groundwater run-off and managed drainage affected the composition and water levels of rivers. Scott's later, I8 Io poem, The Lady of the Lake, the story of which concerns sixteenth-century human conflict on the geological fault that marks the border between the Highlands and Lowlands, notoriously includes an anachronistic reference to that very matter of land use change in the Borders (anachronistic because what is being described was actually the result of changes in times much closer to Scott's own):

From Yarrow braes and banks of Tweed,

Where the lone streams of Ettrick glide,

And from the silver Teviot's side;

The dales, where martial clans did ride,

Are now one sheep-walk, waste and wide. ${ }^{53}$

Those lines spoken by Roderick Dhu also identify four Borders rivers, each of which meant a great deal to Scott: the Yarrow, Ettrick, Teviot and Tweed. Indeed, the first three are tributaries of the Tweed. Despite significant changes in land use, including 'the sheep-walk, waste and wide', and a number of artificial alterations in their own courses, the rivers together constitute images of permanency over that of mutability. If we read Roderick Dhu's words as intertextual dialogue as well as a statement about environmental degradation, they reflect on Scott's first poem from five years earlier in I 805 , The Lay of the Last Minstrel. ${ }^{54}$

The 'last minstrel' as the main character in the frame narrative of The Lay wanders alone, a creative composite from medieval romance (Scott was deeply influenced by the Italian Romance poets Pulci, Ariosto, Boiardo and Tasso), Scottish Borders folklore and a Romantic peripatetic Wordsworthian solitary. He is a figure strangely out of time and place, with no one to sing to and no one to hear him.

Culturally reduced to the status of a sturdy beggar or vagabond, Scott's Minstrel's harp is out of tune. He walks until he comes to a castle by a river, where he is offered lodging, regains his ability to sing and play and using all of the tropes of chivalric love and martial action - brings alive 
after a banquet a vigorous tale of knights and Ladyes, goblin pages, enchanted woods and magic books. Indeed, the minstrel is able to sing again only when he passes 'where Newark's stately tower / Looks out from Yarrow's birchen bower' (27-28). The river Yarrow not only features at eleven other points in the poem but becomes the place where the minstrel finally makes a new home that enables him to continue singing. $\mathrm{He}$ chooses a cottage close to its banks where he can hear its music, rather than reside in the castle. Again, Scott draws attention to the connection between storytelling and the land, in this instance not through subsoil but the sound of flowing water:

When throstles sung in Hare-head shaw, And corn waved green on Carterhaugh, And flourished, broad, Blackandro's oak, The aged Harper's soul awoke! Then would he sing achievements high, And circumstance of chivalry, Till the rapt traveller would stay, Forgetful of the closing day; And noble youths, the strain to hear, Forsook the hunting of the deer; And Yarrow, as he rolled along, Bore burden to the Minstrel's song.

$$
(6: 576-587)
$$

Scott was writing here about rivers that had materially inspired his own imagination. As mentioned, his houses at Ashiestiel and Abbotsford were both close to the banks of the Tweed, at points downriver from its confluence with the Yarrow. A well-known anecdote is that when Scott was dying, he asked to be brought back to Abbotsford so that he could hear the sound of the Tweed once more from his bedroom. The river is indeed audible from Abbotsford House.

\section{Looking Forward: Land Ethics and Moral Values}

This introduction has explored a small segment of Scott's attention to the land and his interest in the developments of environmental management in Scotland. My aim has been to provide a preliminary investigation of how his storytelling drew public attention to real ecological problems, and how the agency of his writing mediates relationships between memory, mythmaking and the biosphere. That investigation shows why it is necessary to look comparatively across the range of Scott's writing within the 
rest of this book, with attention to topical debates and concerns about environmental degradation and land use at the time that he was writing. Only then can we understand the extent and importance of the history of Scotland's environment that he provides. Scott's dexterity in using different kinds of writing - poetry, fiction, letters, journals and official documents including statements to Parliament - in its turn responded to a variety of already existing texts including ancient ballads, treatises on aesthetics and land surveys. In so doing his response to Scotland's evolving ecologies closely matches Scott Slovic's definition of the environmental humanities as a set of related and intersecting discourses embodying 'a loosely shared vision or set of concerns', in which agency is produced from solidarity in diversity. ${ }^{55}$ Strength founded in unity in diversity has long been recognized as the foundation of Walter Scott's writing about Scotland as a meeting point of diverse cultures and social practices, and as the underpinning motivation for his belief in the political union of the United Kingdom. A question that demands an answer, then, is whether Scott's writing about the environment is more than a process of instrumentalizing the land. Are his trees, rivers and the soil points of origin merely for a nationalism that functions by representing Scots as intimately related to the land on which they live? It would be wrong to claim that Scott was not interested in the political and social identity of Scotland.

I raised an early question as to whether Scott anticipated an approach to the land that might be considered in any way similar to the concept of a land ethic proposed by Aldo Leopold. Leopold stated that humankind needed to change from 'conqueror of the land-community to plain member and citizen of it'. He argued that an 'ecological interpretation of history' shows man to be 'only a member of a biotic team' in which 'the characteristics of the land determined the men who lived on it'. ${ }^{56}$ History is a keyword and the past tense imperative here, for the land ethic is described as an evolutionary social process 'impeded' by a social morality according to which 'the space between cities' means little to people who imagine they have 'outgrown the land'. Scott's voice can be heard to resonate in that argument. Moreover, Devin Griffiths has persuasively shown how 'the literary mode that made it possible to narrate the evolutionary past convincingly [was] the historical novel, particularly as authored by Scott'. ${ }^{57}$

Timothy Morton exchanges Leopold's bio-socio-political approach for an aesthetics-based ecological ethics. Drawing attention to philological connections between popular culture (kitsch) and drawings that comprise outline without detail (sketches), he urges differentiation between what he 
calls the Romantic 'kitsch' 'nature' of $A$ Sand County Almanac and the 'anything but sketchy' particularity of Leopold's 'Land Ethics' essay. Morton suggests that an ecological ethics might more authentically take account of Michel Serres' privileging of 'appreciative listening' over 'mastery and possession'. ${ }^{8}$ Serres, in turn, is adamant that a 'natural contract' of attention and contemplation, where knowledge is decoupled from property, be added to the social contract (an Enlightenment principle). In the following chapters we will discover plenty of listening in Scott's writing, especially of a kind that counterpoints instances of change in land use. Whether he advocates an ethics of land and its ecologies, or a natural contract that regulates power defined by property laws, will be explored though attention to his critique of environmental negligence and irresponsibility. That critique, as I shall show, is sustained through storytelling along with a series of remarks and digressions that continually engage with topical ecological anxieties including overfishing, the extension of sheep farming and the planting of non-native trees in unsuitable locations.

The problem of fetishization of the land for national interests remains. Jane Bennett warns that we should be cautious of the urge always to demystify the vitality with which the non-human is invested in literature. ${ }^{59}$ On the one hand, the assumption that human agency has always been 'illicitly projected into things' is acknowledged by Bennett to be a valuable theory for exposing hidden systems of socio-political domination. The pastoral mode and aesthetics of the picturesque referred to earlier in this chapter must surely be included in the exercise of such political and ideological power. But on the other hand, Bennett warns that habitual demystification can obscure the existence of a subversive vitality through which the non-human in the environment acts in its own ways, challenging the authority of anthropocentric control. The echo of human agency in sympathy with non-human nature emerges as a necessary counter to many of the abuses of power that result in violence towards the land. Scott's emphasis on the marvellous power of the soil as an originary source for Scottish literature in 'Thomas the Rhymer', his recourse to the Tweed to recover the sound of the border minstrels and his depiction of Flora Mac-Ivor's place in a Highland ecology all bear out that argument. The disrupted grounds of the modernized estate at TullyVeolan become increasingly troubling. Ultimately, the contribution that Scott made to writing the environmental history of Scotland needs to be read in terms of what he represented, and of what further might be expected, by way of a recognition of the value of the land not just as property, but in itself. 